\section{ATTENTION AROUSED}

Attention in Neurophysiology

Edited by C. R. Evans and T. B. Mulholland. (An International Conference.) Pp. xxii +447 . (Butterworth: London, March 1970.) 200s.

WHEN one is asked to pay $£ 10$ for some 400 or more pages of scientific information, it is pertinent to ask: is it worth it ? The answers are usually various, conditioned by the standing of the authors and the "attention" the subject engenders. This book, a collection of papers given at a symposium in 1967, includes authors of considerable standing on a subject that opens up a refreshingly new interdisciplinary field. If it has failings, they are that attention is, in spite of the discussions presented, still ill-defined in neurophysiological terms, though a wide range of phenomena ranging from heart rate regulation to neurochemical indicators of cortical activity have been investigated. Most of the book contains papers that assume that attention should be related to EEG activity, and that the alpha rhythm is of neuronal origin. An immense amount of effort has gone into quantifying EEG data; for example, the superb presentation of the changes in power spectra by Ross Adey of California, largely derived from his research into "space biology". Creutzfeldt of Munich also presents valuable data on the rhythm of the EEG and the changes during mental tasks.

Only a fow participants dared to raise questions as to the probable basis of the EEG. Mulholland, of Bedford (USA), does ask just this question, pointing out that it is related to eye position and suggesting that the alpha rhythm reflects the behaviour of the visual control system; while Grey Walter of Bristol questions whether attention can ever be defined neurophysiologically. Dewan of the US Air Force puts forward the intriguing idea that there is a control system for the control system, and that some of the recorded EEG patterns are "test signals" used to assess the potential response of the principal control system, an obvious analogy with techniques for space exploration.

Much of the discussion is reproduced and one infers at times that much more was exchanged between the participants than appears in print-inevitable but frustrating to those excluded from the meeting. This all serves to arouse "attention" and these papers serve as an admirable starting point for anybody so stimulated to enter the field. They should be aware, however, that the very basis of most of the work, the alpha rhythm, is open now to critical questioning in respect of its origins, but one hopes that further understanding of it will in time help to define attention in neurophysiological terms more precisely.

J. L. MaLcolm

\section{DRUG COMPENDIUM}

\section{All About Drugs}

By Franz Bergel and D. R. A. Davies. With the collaboration of Peter Ford. Pp. $x+203$. (Nelson: London, January 1970.) $42 s$.

THIS is a slightly strange but rather enjoyable book about a well known subject. It is enjoyable because it is well written, compact, informative and readable-but above all, because it seeks from the first page to cool the steaming current of emotion in which most discussions of the subject are whirled about, to give valid information and to state clearly the desirable goals. Perhaps inevitably, the positive recommendations made are largely technical (that is to say, legal or scientific in nature) and so are seemingly addressed to an inappropriate audience.

But it is also a strange book; the title is designed for six year olds, the text for the intelligent middle-aged, and the reference list for fairly senior specialists of different kinds, or at least for people with some time to spare and a good deal of familiarity in using unusual libraries. It is a strange book, too, because one would not have expected to find in a book of such distinguished authorship the number of misprints that have survived (for example, Professor Paton did not contribute to a famous book by the Chopras; there is no doubt that HMSO did indeed publish the "Wootton Report"; "Artane" is benzhexol; "Datura" is spelt as here). Nor would one have expected quite so much out of date information as, for instance, on the barbiturates: the traditional multiple classification by their mostly quite undistinguishable durations of action (with one or two exceptions) is now largely discredited--and, a more serious matter, the lack of emphasis upon the potentially lethal consequence of sudden withdrawal of barbiturates from those physically dependent upon them: a much more dangerous state of affairs than the corresponding sudden withdrawal of opiates. There are also occasional downright inaccuracies-Melsedin is not the mixture of methaqualone and diphenhydramine that has recently become subject to widespread abuse: indeed, it does not contain diphenhydramine at all. It is strange, too, that the text uses such archaic concepts as "poisoning"- - otherwise unspecified-to illustrate, for example, by the case of Honoré de Balzac, the dangers of excessive use of caffeine. The statement not only fails to make it clear whether Balzac died of a surfeit of coffee or would have been a better writer had he indulged in it less, but is undocumented-like a surprisingly large number of the other statements in a book with so many references.

The book is not, in fact, all about all drugs, but only a certain amount about some drugs which act on the central nervous system. The point is made perfectly clear in the introductory chapter, but it is a slight pity that drugs have, once again, been equated with a very specific subclass in the minds of those who read no further than the title of a book.

C. R. B. Joyce

\section{THOSE WOOLLY COTTON EFFECTS}

\section{Optical Rotatory Dispersion of Proteins and Other} Macromolecules

By B. Jirgensons. (Molecular Biology, Biochemistry, and Biophysies, Vol. 5.) Pp. xi +166 . (Springer-Verlag; Berlin and New York, 1969.) 46 DM; \$12.70.

Just as the nuns who tended the lepers in Africa were said to have resented most bitterly the advent of drugs that worked, so many protein chemists must have felt, when the efforts of the crystallographers bore fruit, that their fun had been spoiled for good. A devoted band, however, remained at their posts, measuring axial ratios and helical contents with undimmed resolve, and, let it be said, ever-increasing precision, if not necessarily accuracy. Others again became preoccupied with different problems, feeling perhaps that the place of the physical chemist in protein chemistry is less to pursue low-grade answers to structural questions than to grapple with the thermodynamic and kinetic problems that arose in many cases from the structural features that the $X$-ray analyses revealed. Here spectroscopic methods and particularly optical rotatory dispersion and circular dichroism have undoubtedly played an important part; even, therefore, if the structural information that they are able to deliver is of a low order, their placo in protein chemistry is secure, and workers in the field will want to understand, so far as the present state of theory allows, the basis of the methods.

Dr Jirgensons, alas, is unlikely to help them. His book is pitched at an entirely empirical level. The underlying theory scarcely breaks surface, and instrumental aspects of the measurements are discussed without, for example, a definition of the Faraday effect. Instead, there is a large picture of a cell, some manufacturers's optical diagrams and plates of a Cary and a Rudolph polarimeter, 